\title{
Peran Komunitas Jaga Sesama Terhadap Penguatan Sikap Toleransi Sebagai Perwujudan Nilai Ketuhanan Yang Maha Esa
}

\author{
Erna Gesti Fadrusiana \\ Sekolah Menengah Kejuruan Empat Lima Surakarta \\ Email: ernagesfana@gmail.com
}

\begin{abstract}
ABSTRAK
Komunitas Jaga Sesama adalah salah satu komunitas agama di Surakarta yang memiliki visi misi untuk menciptakan wadah bagi pemuda yang kesulitan mencari guru ngaji untuk dapat belajar agama. Tujuan dari penelitian ini untuk mengetahui peran komunitas Jaga Sesama melalui kegiatankegiatannya terhadap penguatan sikap toleransi sehingga dapat mewujudkan nilai Ketuhanan Yang Maha Esa. Penelitian ini menggunakan metode kualitatif dengan enam subjek penelitian yaitu anggota komunitas Jaga Sesama. Pengumpulan data dengan cara wawancara, observasi dan dokumen. Hasil penelitian menunjukkan bahwa komunitas Jaga Sesama melalui kegiatan Jaga Sesama (Belajar Mengaji Setiap Selasa Malam) dan Mbois (Membahas Obrolan Islami) memiliki peran terhadap penguatan sikap toleransi pemuda yang dibuktikan dari sikap mau menerima perbedaan latar belakang anggota, membantu anggota dalam belajar membaca al qur'an serta sholat, mau menerima perbedaan pendapat maupun perbedaan keyakinan dengan orang lain sehingga dapat mewujudkan nilai Ketuhanan Yang Maha Esa.
\end{abstract}

Kata kunci: peran, komunitas, sikap, toleransi, Ketuhanan Yang Maha Esa

\section{PENDAHULUAN}

Indonesia adalah salah satu Negara majemuk dengan berbagai macam agama yang dianut oleh warganya yaitu Islam, Kristen, Katholik, Hindu, Budha serta Khong $\mathrm{Hu}$ Chu. Sejak dahulu, dalam kehidupan sehari-hari masyarakat berinteraksi sosial antar umat beragama. Kerukunan menjadi salah satu dasar kesejahteraan. Indonesia memiliki dasar Negara yaitu Pancasila. Pancasila memiliki kedudukan dan fungsi antara lain sebagai jiwa bangsa Indonesia, sebagai kepribadian bangsa Indonesia, sebagai pandangan hidup bangsa Indonesia, sebagai falsafah hidup Bangsa Indonesia, sebagai Ideologi Negara Republik Indonesia, sebagai sumber hokum nasional serta sebagai perjanjian luhur bangsa Indonesia (Munir dkk, 2016).

Sila Pertama yaitu Ketuhanan Yang Maha Esa memiliki makna percaya dan taqwa kepada Tuhan Yang Maha Esa sesuai dengan agama dan kepercayaannya (Erwin, 2013). Dari pernyataan tersebut dapat dikatakan bahwa sebagai warga Negara berhak untuk beribadah kepada Tuhannya sesuai dengan agama yang dianutnya. Pada perkembangan jaman saat ini, banyak komunitas pemuda yang mempunyai kegiatan-kegiatan berkaitan dengan 
agama. Tujuannya adalah untuk memperkuat sikap pada diri pemuda agar lebih dekat kepada penciptanya, memiliki perilaku yang baik terhadap sekitar serta membawa perubahan pada pribadinya. Di Indonesia masih banyak kasus permasalahan mengenai agama. Sepanjang tahun 2019, terjadi 31 kasus kasus intoleransi atau pelanggaran kebebasan beragama dan berkeyakinan di Indonesia. Sejumlah 28 kasus di antaranya dilakukan oleh warga setempat yang dimobilisasi oleh organisasi atau kelompok agama tertentu (https://www.gatra.com/). Melihat adanya beberapa kasus intoleransi tersebut, terdapat komunitas-komunitas agama yang mempunyai visi misi menyediakan wadah untuk dapat belajar agama dikarenakan sulit menemukan wadah yang mau menerima pemuda dengan latar belakang kurang baik, salah satunya yaitu Komunitas Jaga Sesama. Soenarno (2002) menyebutkan, "Komunitas adalah sebuah identifikasi dan interaksi sosial yang dibangun dengan berbagai dimensi kebutuhan fungsional". Komunitas ini didirikan oleh pemudapemuda kota Surakarta pada tanggal 26 Januari 2016 dengan anggota awal adalah empat orang. Mereka memiliki ide untuk membentuk komunitas dikarenakan rasa gelisah ingin belajar agama namun belum menemukan guru mengaji maupun wadah/tempat yang mau untuk menerima mereka. Hal itu disebabkan latar belakang pemuda yang kurang baik atau dapat dikatakan melanggar norma/hukum yang ada di sekitarnya seperti pemabuk, pecandu obat-obatan terlarang, preman dan sebagainya. Seiring berjalannya waktu, anggota komunitas ini pun berasal dari berbagai macam latar belakang dan juga usia.

Komunitas Jaga Sesama memiliki kegiatan yaitu Jaga Sesama (Belajar Mengaji Setiap Selasa Malam) dan Mbois (Mbahas Obrolan Islami). Kegiatan ini rutin diselenggarakan setiap hari selasa dan juga akhir bulan. Komunitas Jaga Sesama bertempat Masjid ArRochman. Tujuan dari kegiatan dalam Komunitas ini yaitu untuk membantu ataupun berperan menumbuhkan sikap yang baik dalam diri anggotanya yang nantinya dapat membawa dampak baik juga terhadap sekitar. Peran dipengaruhi oleh keadaan sosial baik dari dalam maupun dari luar dan bersifat sosial (Soekanto, 2002). Lalu Allport menyatakan, "sikap merupakan kesiapan mental yaitu suatu proses yang berlangsung dalam diri seseorang bersama dengan pengalaman individual masingmasing mengarahkan dan menentukan respon terhadap berbagai objek dan situasi" (Sarwono, 2009). Sedangkan ciri-ciri sikap menurut Ahmadi (1990) yaitu 1) sikap itu dipelajari (learnability) artinya beberapa sikap bisa dipelajari dengan tidak sengaja dan tanpa kesadaran 
pada sebagian individu. Kemudian juga dapat dengan mempelajari sikap dengan sengaja apabila individu sadar bahwa hal itu dapat membawa kebaikan (untuk diri sendiri), membantu tujuan kelompok atau memperoleh suatu nilai yang sifatnya perseorangan; 2) memiliki kestabilan (stability) yaitu bermula dari dipelajari terlebih dahulu lalu mejadi lebih kuat, tetap, stabil serta melalui suatu pengalaman; 3) sikap melibatkan hubungan antara seseorang dengan orang lain maupun antara orang dan barang atau situasi; 4) sikap berisi informasi yang factual; 5) orang yang memiliki sikap yang baik terhadap suatu objek maka mereka akan mendekati dan membantunya, begitu pula sebaliknya.

Untuk dapat memahami toleransi, terlebih dahulu perlu memahami mengenai sikap religius. Sikap religius merupakan sikap yang wajib dimiliki oleh setiap orang karena hal tersebut menunjukan hubungan antara makhluk hidup kepada Tuhannya sesuai dengan perintah agamanya. Daradjat (2005) menyatakan, "agama merupakan proses hubungan yang dirasakan terhadap sesuatu yang diyakininya, bahwa sesuatu lebih tinggi daripada manusia”. Seseorang yang memiliki religiusitas yang baik pasti dapat maknai setiap ajaran yang ada dalam agama, salah satunya bersikap toleransi kepada sesama. Toleransi beragama menurut Islam menegaskan bahwa Islam merupakan agama yang benar di hadirat Allah tetapi mengajarkan menghormati terhadap keyakinan lain dalam berbuat serta bersikap adil (Basyir, 2013). Sebagai umat beragama, dalam ajaran agama kita diajarkan untuk dapat bersikap baik terhadap sesama meskipun berbeda keyakinan dan dalam aspek kehidupan lainnya selama tidak bertentangan dengan aturan agama.

Penelitian mengenai toleransi juga dilakukan oleh Rina Hermawati, dkk (2016) yang memperoleh hasil bahwa toleransi antar umat beragama di kota Bandung tergolong tinggi. Di mana interaksi social antarumat beragama berlangsung dengan baik serta menerima keberadaan pemeluk agama yang berbeda. Namun juga masih ada isu-isu agama yang dapat memicu konflik dengan factor pemicu berbasis identitas in group dan out group sehingga pemerintah kota Bandung melalui Forum Kerukunan Umat Beragama dan pendidikan multicultural berupaya meningkatkan peran untuk meminimalisir resiko konflik. Berbeda dengan temuan tersebut, dalam tulisan ini peneliti ingin menguraikan mengenai peran Komunitas Jaga Sesama terhadap penguatan sikap toleransi sebagai salah satu perwujudan nilai Ketuhanan Yang Maha Esa. 


\section{METODE PENELITIAN}

Penelitian dilakukan di Komunitas Jaga Sesama yang berlokasi di masjid Ar-Rachman Manahan, Surakarta. Penelitian ini menggunakan metode penelitian kualitatif. Pengumpulan data menggunakan teknik wawancara, observasi dan dokumen. Teknik wawancara dilakukan pada enam orang yang terdiri dari pendiri dan anggota. Observasi dilakukan pada saat kegiatan mengaji dan mbois selama dua bulan. Uji validitas data dengan menggunakan trianggulasi data dan trianggulasi metode. Pengambilan subjek penelitian dengan purposive sampling dengan jumlah enam orang. Teknik analisis data melalui tahap prosedur reduksi data, penyajian data dan yang terakhir penarikan kesimpulan. Sedangkan untuk prosedur penelitian melalui tiga tahap yaitu persiapan, pelaksanaan dilanjutkan dengan penyusunan laporan.

\section{PEMBAHASAN}

Tujuan dari penelitian ini adalah untuk mengetahui peran komunitas Jaga Sesama terhadap penguatan sikap religius sebagai perwujudan dari nilai Ketuhanan yang Maha Esa. Dalam kehidupan bermasyarakat, terdapat beberapa komunitas yang dipelopori oleh masyarakat. Komunitas merupakan sekelompok manusia yang memiliki rasa peduli satu sama lain yang lebih dari biasanya atau lebih dari yang seharusnya. Artinya komunitas adalah kelompok orang yang saling mendukung serta saling membantu (Hermawan, 2008). Jaga Sesama termasuk suatu komunitas karena anggotanya memiliki rasa saling peduli. Komunitas ini memiliki anggota kurang lebih 150 orang baik laki-laki maupun perempuan. Tidak ada syarat khusus untuk dapat bergabung di Jaga Sesama hanya komitmen untuk menjadi pribadi yang lebih baik. Kegiatan dalam komunitas ini dikenal melalui postingan-postingan di media social instagram seperti Jaga Sesama (Belajar Mengaji Bersama Selasa Malam). Berfiqir (Belajar Fiqih Bersama Rabu Malam), serta Mbois (Membahas Obrolan Islami) namun pada penelitian ini hanya berfokus pada kegiatan mengaji dan Mbois. Keteraturan dalam memposting kegiatan membuat masyarakat tertarik untuk bergabung komunitas.

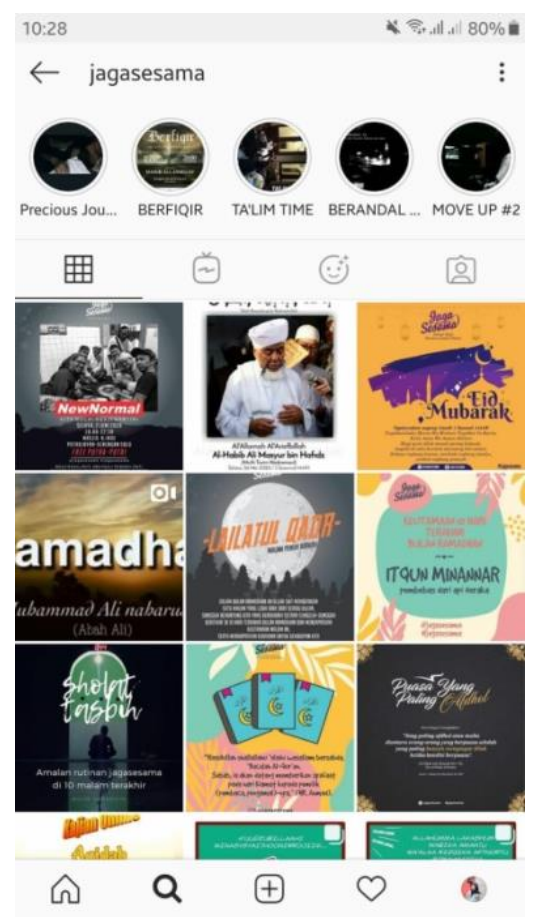




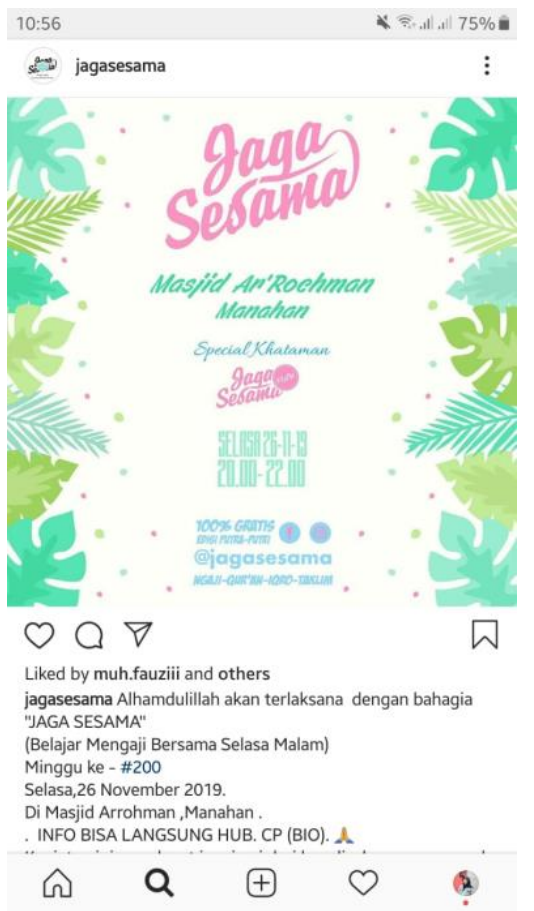

Sumber: Instagram Jaga Sesama
Anggota yang bergabung memiliki latar belakang yang berbeda-beda mulai dari mantan preman, mantan pemabuk tetapi berkeinginan berubah menjadi pribadi religius yang lebih baik. Setiap kali diadakan kegaiatan rutin, anggota yang hadir kurang lebih 30 orang sesuai dengan pernyataan dari pendiri komunitas, "anggota yang hadir pada setiap kegiatan kurang lebih ada 30 orang. Waktu kegiatan kami pilih malam hari karena menyesuaikan dengan waktu luang mayoritas anggota karena jika pagi hari para anggota masih bekerja". Kegiatan-kegiatan tersebut biasa dimulai pukul 20.30 dan berakhir pada pukul 22.00. Berikut hasil observasi yang ditemukan oleh peneliti di lapangan:

\begin{tabular}{|c|c|c|}
\hline No & Kegiatan & $\begin{array}{ll}\text { Ya } & \text { Tidak }\end{array}$ \\
\hline 1 & Kegiatan rutin diadakan setiap minggu & $\sqrt{ }$ \\
\hline 2 & Anggota mengikuti kegiatan dengan antusias & $\sqrt{ }$ \\
\hline 3 & $\begin{array}{l}\text { Kegiatan diikuti oleh anggota dari berbagai latar } \\
\text { belakang }\end{array}$ & \\
\hline 4 & $\begin{array}{l}\text { Komunitas menyediakan perlengkapan pendukung } \\
\text { kegiatan seperti al quran/iqro' }\end{array}$ & \\
\hline 5 & $\begin{array}{l}\text { Anggota saling membantu dalam belajar membaca al } \\
\text { qur'an }\end{array}$ & $\sqrt{ }$ \\
\hline 6 & Kegiatan terbuka untuk umum dan gratis & $\sqrt{ }$ \\
\hline 7 & Ada evaluasi setelah kegiatan berlangsung & $\sqrt{ }$ \\
\hline 8 & $\begin{array}{l}\text { Kegiatan Mbois diadakan sebulan sekali pada akhir } \\
\text { bulan }\end{array}$ & \\
\hline 9 & Ada diskusi bersama anggota komunitas & $\sqrt{ }$ \\
\hline 10 & $\begin{array}{l}\text { Adanya rasa saling menghormati dan menghargai antar } \\
\text { anggota yang terlihat ketika kegiatan berlangsung }\end{array}$ & $\sqrt{ }$ \\
\hline
\end{tabular}

Sumber: Hasil Observasi Peneliti 
Hasil wawancara dengan anggota bernama Dimas, beliau menjelaskan bahwa saat mulai bergabung ia diterima dengan baik, tidak ada syarat khusus untuk bergabung dengan komunitas bahkan hubungan antar anggota juga sangat baik, mereka mau membantu untuk belajar beribadah seperti cara sholat yang baik. Anggota lain yaitu Bagus pun mengaku ia sangat dibantu oleh teman sesama anggota untuk belajar berwudhu karena selama ini ia masih jarang menunaikan sholat. Fitri sebagai anggota putri di komunitas menambahkan bahwa ia mau membantu teman untuk belajar beribadah atau mengaji karena baginya membagi ilmu merupakan kewajiban sesama manusia terlebih kepada sesama umat beragama untuk sesuatu yang menyangkut hubungan manusia dengan Tuhannya. Wawancara selanjutnya bersama Malkan menjelaskan bahwa meskipun mereka bergabung dengan komunitas baru diluar lingkup pertemanan mereka yang sebelumnya tetapi tetap menjaga pertemanan dengan baik meski berbeda agama. Beliau mengaku teman-temannya memiliki agama yang berbeda dengannya namun tetap bertoleransi ketika mereka akan beribadah dan tetap menghormati dan menghargai ajaran agamanya.

Dari hasil observasi dan studi dokumen juga diperoleh bahwa saat adanya diskusi, anggota mau mendengarkan dan menghargai pendapat orang lain meskipun pendapat mereka berbeda-beda. Sebagai contoh adalah saat akan menetapkan pengisi acara untuk kegiatan Mbois, mereka berdiskusi untuk memilih ustadz yang akan diundang untuk hadir mengisi kegiatan pada acara tersebut. Anggota memberikan beberapa pilihan ustadz lalu didiskusikan bersama untuk menetapkan salah satu ustadznya.

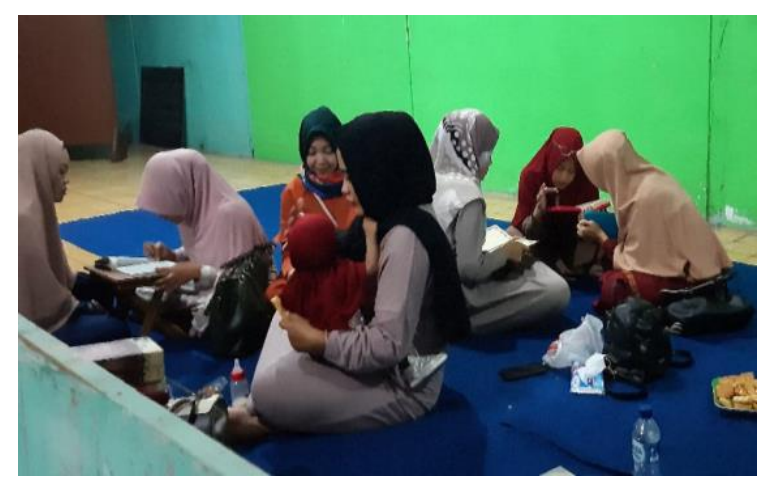

Gambar 2.1. Anggota belajar membaca al quran bersama

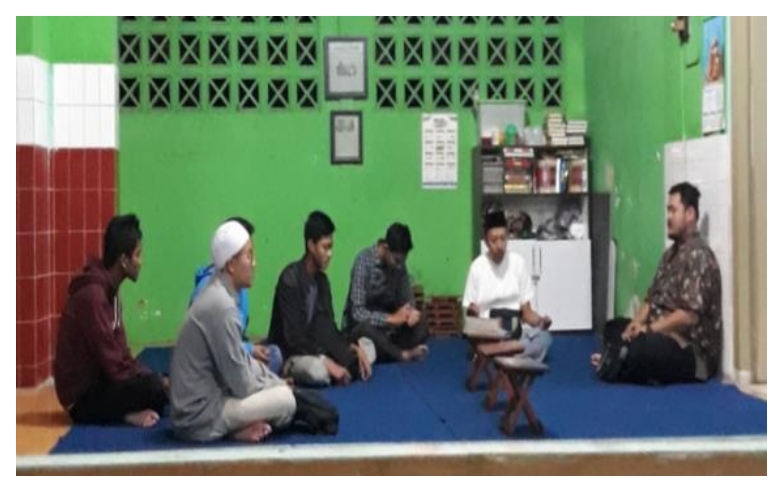

Gambar 2.2. Anggota melakukan diskusi sekaligus evaluasi kegiatan

Sumber: Dokumentasi Pribadi Peneliti

Di dalam komunitas Jaga Sesama, anggota yang bergabung pun 
memiliki latar belakang organisasi yang berbeda-beda, ada Muhammadiyah, NU, LDII dan lainnya. Namun ketika akan bergabung di komunitas, hal tersebut tidak menjadi kendala karena yang terpenting adalah kemauan untuk belajar agama secara lebih maksimal. Di sekitar masjid Ar-Rachman tempat komunitas Jaga Sesama ini berada, masyarakat sekitarnya beragama nonmuslim. Meski demikian, mereka mau menerima komunitas ini dengan memperbolehkan menggunakan masjid Ar-Rachman sebagai tempat berkumpul atau biasa mereka sebut sebagai basecamp untuk kegiatan komunitas. Sikap toleransi yang dilakukan ini boleh patut untuk dicontoh dan diteruskan agar tetap terjalin kerukunan antar masyarakat serta antar umat beragama. Hal inilah yang dijadikan pelajaran oleh anggota komunitas utnuk dapat bersikap toleransi terhadap sesama maupun antar umat beragama. Walaupun komunitas diberikan kebebasan untuk menggunakan masjid, namun mereka tetap memperhatikan waktu dalam melaksanakan kegiatan sehingga tidak mengganggu warga sekitar.

Berdasarkan hasil penelitian yang diperoleh, komunitas memiliki peran yang sejalan dengan pendapat Soekanto (2002) yang mengatakan peran adalah seperangkat tingkah laku individu terhadap seseorang agar kedudukan dalam suatu sistem berjalan dengan baik. Pendapat ini sesuai dengan hasil yang diperoleh bahwa komunitas Jaga Sesama memiliki tindakan terhadap komunitas yang terdiri dari beberapa orang agar nantinya kehidupan dalam suatu bermasyarakat dapat berjalan sesuai dengan tujuan yaitu mewujudkan nilai Ketuhanan Yang Maha Esa.

Selanjutnya, hasil penelitian sesuai dengan pendapat yang telah dijelaskan sebelumnya oleh Basyir (2013) bahwa Islam mewajibkan untuk menghormati keyakinan lain baik dalam berbuat maupun bersikap. Verkuyten (2010) menyatakan bahwa toleransi dikonsepkan melalui berbagai cara seperti menghargai setiap perbedaan yang ada, tidak berprasangka satu sama lain, mau menerima sesuatu yang tidak sesuai atau dibenci orang lain. Lebih lanjut, hasil penelitian sejalan dengan pendapat Al Munawar (2005) yang mengatakan bahwa prinsip toleransi diantaranya yaitu: 1) prinsip kebebasan beragama (religious freedom) yang mana ditunjukkan dari sikap anggota yang memberikan kebebasan pada orang lain untuk menganut agama; 2) prinsip acceptance, ditunjukkan dari sikap mau menerima anggota lain yang berasal dari latar belakang yang berbeda; 3) berfikir positif serta percaya (positive thinking and trustworthy) yaitu tampak dari sikap anggota saat menerima nggota baru, mereka yakin bahwa calon anggota baru tersebut memiliki niat untuk menjadi pribadi yang lebih baik 
dengan berusaha memperbaiki ibadahnya.

Sedangkan jika dibahas berdasarkan Nilai Ketuhanan Yang Maha Esa, hasil yang diperoleh sejalan dengan pendapat Nurhadianto (2014) yang menyatakan nilai-nilai tersebut berupa 1) mengembangkan sikap hormat-menghormati dan bekerja sama antara pemeluk agama dan penganut kepercayaan yang berbeda yang terlihat dari sikap anggota untuk mau membimbing anggota lain untuk mempelajari agama; 2) membina kerukunan hidup diantara sesama umat beragama dan kepercayaan terhadap Tuhan Yang Maha Esa. Sesuai dengan hasil penelitian yang menunjukkan kerukunan dengan sesama anggota maupun dengan warga sekitar; 3) mengembangkan sikap saling menghormati kebebasan menjalankan ibadah sesuai dengan agama dan kepercayaan masingmasing. Hal ini ditunjukkan dari hasil di mana anggota mau menghormati warga lain di sekitar masjid untuk beribadah sesuai keyakinannya terlebih letak masjid yang tidak jauh dari Gereja Manahan; 4) tidak memaksakan suatu agama dan kepercayaan terhadap Tuhan Yang Maha Esa kepada orang lain. Sesuai dengan hasil penelitian yang menjelaskan bahwa anggota tetap bergaul dengan orang lain yang berbeda keyakinan selama tidak bertentangan dengan ajaran agama, tidak memaksakan orang lain untuk beribadah sesuai agamanya.

\section{SIMPULAN}

Kegiatan-kegiatan yang diadakan oleh komunitas Jaga Sesama yaitu mengaji dan Mbois memiliki peran penting bagi anggotanya. Hasil tersebut diperoleh dari wawancara, observasi serta dokumen yang menyatakan bahwa kegiatan komunitas membantu anggota dalam memperkuat sikap toleransi. Sikap toleransi yang diperkuat diantaranya mau menerima anggota yang bergabung walau dari beragam latar belakang, mau membimbing anggota lain untuk belajar membaca al quran, menghargai setiap perbedaan pendapat serta menghargai dan menghormati orang lain yang berbeda keyakinan dengannya. Sehingga dengan adanya peran yang dilakukan oleh komunitas Jaga Sesama ini dapat mewujudkan nilai Pancasila salah satunya Ketuhanan Yang Maha Esa. 


\section{DAFTAR PUSTAKA}

Ahmadi, Abu. 1990. Psikologi Sosial. Surabaya: Bina Ilmu.

Al Munawar, Said Agil Husin. 2005. Fikih Hubungan Antar Agama. Ciputat: Ciputat Press.

Basyir, Azhar. 2013. Akidah Islam (Beragama Secara Dewasa). Yogyakarta: UII Press.

Daradjat, Zakiyah. 2005. Ilmu Jiwa Agama. Jakarta: Bulan Bintang.

Munir, dkk. 2016. Pendidikan Pancasila. Malang: Madani Media.

Nurhadianto. 2014. Internalisasi Nilai-Nilai Pancasila dalam Upaya Membentuk pelajar Anti Narkoba. Jurnal Pendidikan Ilmu Sosial, Volume 23, No 2.

Rina Hermawati, dkk. 2016. Toleransi Antar Umat Beragama di Kota Bandung. Indonesian Journal of Anthropology, Vol. 1 (2).

Sarwono, dkk. 2009. Psikologi Sosial. Jakarta: Salemba Humanika.

Soekanto, Soerjono. 2002. Teori Peranan. Jakarta: Bumi Aksara.

Verkuyten, M. (2010). Multiculturalism and Tolerance: An Intergroup Perspective. The Psychology of Social and Cultural Diversity, 145-170. https://doi.org/10.1002/9781444325447.ch7

https://www.gatra.com/detail/news/457157/politik/sepanjang-2019-imparsialsebut-31-kasus-intoleransi-di-indonesia diakses pada 02 Juni 2020 